\title{
JNPH
}

Volume 5 No. 2 (Desember 2017)

(C) The Author(s) 2017

\section{UJI BAKTERI COLIFORM PADA OLAHAN BAWANG PUTIH GILING Allium sativum L YANG DI JUAL DI PASAR TRADISIONAL KOTA BENGKULU}

\author{
TEST OF COLIFORM BACTERIA ON DRIED GARLIC PRODUCT Allium sativum L \\ THAT IS SOLD IN TRADITIONAL MARKET OF BENGKULU CITY
}

\author{
JON FARIZAL, PUTRI WIDELIA W \\ POLTEKKES KEMENKES BENGKULU
}

\begin{abstract}
ABSTRAK
Bawang putih sebagai bumbu digunakan hampir dalam setiap makanan dan masakan di indonesia. Pada umumnya pedagang bawang putih giling, dalam pengolahannya tidak mencuci bahan dan peralatannya dengan air bersih, maka diadakan penelitian untuk mengetahui kualitas olahan bawang putih giling yang beredar secara mikrobiologis. Penelitian ini bertujuan untuk mendeteksi keberadaan bakteri coliform pada olahan bawang putih giling yang dijual di Pasar tradisional kota bengkulu. Metode yang digunakan adalah metode deskriptif dengan pengambilan 19 sampel uji dilakukan pengujian dengan menggunakan metode MPN ragam 5-11 yang meliputi uji penduga dan uji penegas kemudian disesuaikan dengan tabel MPN. Hasil penelitian menunjukkan dari 19 sampel yang diperiksa 13 sampel mengandung bakteri coliform dengan cemaran bakteri coliform $68,4 \% / 100 \mathrm{~mL}$, dengan nilai MPN yang tertinggi adalah 10/100 mL sebanyak 3 sampel, dan nilai MPN sample lainnya yaitu $2 / 100 \mathrm{~mL}$ sebanyak 1 sampel, untuk nilai MPN 4/100 ml sebanyak 1 sampel, untuk nilai MPN 7/100 mL sebanyak 2 sampel, untuk nilai MPN 8/100 mL sebanyak 5 sampel, sedangkan untuk nilai MPN 9/100 mL sebanyak 1 sampel. Adanya Bakteri Coliform dalam olahan bawang putih giling yang dijual di pasar tradisional kota Bengkulu sebesar 68,4\%/100 mL.Terdapatnya bakteri coliform dapat diperkirakan yaitu melalui cara pengolahan dan pemasaran serta kondisi pasar tradisional yang buruk.
\end{abstract}

Kata Kunci: bawang putih giling, MPN, coliform

\begin{abstract}
Garlic as a spice is used almost in every food and cuisine in Indonesia. In general, garlic milled traders, in the processing does not wash the material and equipment with clean water, then held a study to determine the quality of processed garlic milling circulating micro biologically. This study aims to detect the presence of coliform bacteria in processed garlic milled sold in the traditional market of bengkulu city. The method used is descriptive method by taking 19 test samples are tested by using MPN method 5-1-1 range which includes test predictors and assertion tests then adjusted to the table MPN. The results showed that 19 samples were examined 13 samples containing coliform bacteria with coliform bacteria contamination of $68.4 \%$ / $100 \mathrm{~mL}$, with the highest MPN value was $10 / 100 \mathrm{~mL}$ of 3 samples, and other sample MPN value that is $2 / 100 \mathrm{~mL}$ as much as 1 sample, for MPN 4/100 ml value of 1 sample, for MPN 7/100 mL value of 2 samples, for MPN 8/100 mL as much as 5 samples, while for MPN 9/100 $\mathrm{mL}$ as much as 1 sample. The presence of Coliform bacteria in processed garlic milled
\end{abstract}


sold in the traditional market of Bengkulu city of $68.4 \%$ / $100 \mathrm{Ml}$. Include of coliform bacteria can be estimated through the way of processing and marketing and traditional market conditions.

\section{Keywords: milled garlic, MPN, coliform}

\section{PENDAHULUAN}

Bawang putih sebagai bumbu digunakan hampir dalam setiap makanan dan masakan di Indonesia, yang menghasilkan rasa dan aroma khas. Tanaman dengan nama latin Allium sativum $L$ ini termasuk bumbu masak yang paling populer di Asia. ${ }^{(1)}$. Pada umumnya pedagang bawang putih giling, dalam pengolahannya tidak mencuci bahan dan peralatannya dengan air bersih. Bawang putih merupakan bahan olahan yang digiling dengan menggunakan mesin penggiling dengan penambahan bahan-bahan lain seperti garam dan air. Pedagang biasanya tidak menggunakan wadah yang tertutup untuk meyimpan bawang putih giling yang telah di olah. Hal ini dapat memberi peluang besar terjadi kontaminasi, baik kontaminasi fisik seperti debu, maupun kontaminasi biologis seperti mikroorganisme. Terlebih lagi melihat kondisi lokasi pasar tradisional yang becek dan lembab dapat memperbesar peluang terjadinya kontaminasi ${ }^{(1)}$.

Makanan merupakan salah satu hal yang sangat penting di dalam kehidupan manusia. Makanan bukan saja harus memenuhi nilai gizi dan mempunyai bentuk yang menarik, akan tetapi juga aman dalam arti tidak mengandung mikroorganisme dan bahanbahan kimia yang dapat menyebabkan penyakit $^{(2)}$.

Coliform, E. Coli dalam minuman dan makanan merupakan indikator terjadinya kontaminasi akibat penanganan minuman yang kurang baik. Minimnya pengetahuan para pembeli mengenai cara mengelolah makanan dan minuman yang sehat dan aman, menambah besar resiko kontaminasi makanan dan minuman yang dijajankannya. ${ }^{(3)}$.

Bakteri coliform adalah golongan bakteri intestinal, yang hidup dalam saluran pencernaan manusia. Bakteri coliform merupakan bakteri indikator keberadaan bakteri patogenik lain. Lebih tepatnya, bakteri coliform fekal. Penentuan coliform fekal menjadi indikator pencemaran dikarenakan jumlah koloninya pasti bekolerasi positif dengan dan sederhana dari pada mendeteksi bakteri patogen lain ${ }^{(4)}$.

Bakteri coliform sebagai indikator sanitasi dimana keberadaannya dalam pangan menunjukan bahwa air atau makanan dan minuman tersebut pernah tercemar oleh feses manusia. Bakteri-bakteri indikator sanitasi umunya adalah bakteri yang lazim terdapat dan hidup pada flora usus manusia. Bakteri Coliform termasuk dalam family Enterobactericeae. ${ }^{(5)}$.

Metode Most Probable Number (MPN) umumnya digunakan untuk menghitung jumlah bakteri khususnya untuk mendeteksi adanya bakteri Coliform yang merupakan kontaminan. Penentuan Coliform Fecal menjadi indikator pencemaran dikarenakan jumlah koloninya pasti berkolerasi positif dengan keberadaan bakteri patogen. Selain itu, mendeteksi Coliform jauh lebih murah, cepat, dan sederhan dari pada mendeteksi bakteri patogenik lain. ${ }^{(6)}$.

Uji Coliform fecal secara lengkap meliputi uji penduga, uji penguat, dan uji lengkap. Ada dua cara yang dapat digunakan untuk menghitung MPN (Most Probable Number) Coliform secara sensitif didalam minuman yaitu metode 7 tabung dan 15 tabung. Dalam uji Coliform Fecal menggunakan media LBDS (Laktosa Broth Dauble Strecht). LBBS (Laktosa Borth Single Strecht) dan BGLB (Bile Green Laktosa Broth) ${ }^{(6)}$.

\section{METODE PENELITIAN}

Metode yang digunakan adalah metode deskriptif dengan pengambilan 19 sampel uji 
dilakukan pengujian dengan menggunakan metode MPN ragam 5-1-1 yang meliputi uji penduga dan uji penegas kemudian disesuaikan dengan tabel MPN.

\section{HASIL PENELITIAN}

Dari penelitian pemeriksaan bakteri coliform diperoleh hasil Distribusi frekuensi pada olahan bawang putih giling yang di Jual di pasar tradisional kota Bengkulu.

Tabel 1 Distribusi frekuensi bakteri Coliform pada olahan bawang putih giling yang dijual di pasar tradisonal kota Bengkulu.

\begin{tabular}{ccc}
\hline Hasil Pemeriksaan & Frekuensi & Persentase(\%) \\
\hline $\begin{array}{c}\text { Positif bakteri } \\
\text { Coliform }\end{array}$ & 13 & $68,4 \%$ \\
\hline $\begin{array}{c}\text { Negatif Bakteri } \\
\text { Coliform }\end{array}$ & 16 & $31,6 \%$ \\
\hline Total & 19 & $100 \%$ \\
\hline
\end{tabular}

Berdasarkan hasil pengamatan yang telah dilakukan, didapatkan bakteri Coliform pada olahan bawang putih giling yang dijual di pasar tradisional kota Bengkulu terkandung bakteri coliform sebesar 13 sampel $(68,4 \%)$.

\section{PEMBAHASAN}

Bakteri coliform pada olahan bawang putih giling yang dijual di pasar tradisional kota Bengkulu nilai MPN yang tertinggi adalah 10/100 mL sebanyak 3 sampel, dan nilai MPN sample lainnya yaitu $2 / 100 \mathrm{~mL}$ sebanyak 1 sampel, untuk nilai MPN 4/100 ml sebanyak 1 sampel, untuk nilai MPN 7/100 mL sebanyak 2 sampel, untuk nilai MPN 8/100 $\mathrm{mL}$ sebanyak 5 sampel, sedangkan untuk nilai MPN 9/100 Ml sebanyak 1 sampel, hasil positif dalam pemeriksaan ini mengandung bakteri coliform.

Hasil sesuai dengan penelitian oleh Pujiana Okta Putri, Mades Fifendy, Periadnadi (2013) didapatkan hasil bahwa Indeks MPN coliform dan E.coli pada bawang putih giling dari beberapa pasar tradisional di kota Padang berkisar Bakteri Coliform 2,2$240 \mathrm{sel} / 100 \mathrm{~mL}$, bakteri E.coli $0-4 \mathrm{sel} / 100 \mathrm{~mL}$ sampel, hal ini membuktikan bahwa bawang putih giling dari beberapa pasar tradisional di kota Padang berkualitas tidak memuaskan. Bawang putih giling dari beberapa pasar tradisional di kota Padang sebagian besar tidak layak dikonsumsi karena mengandung bakteri coliform dan E.coli

Penelitian pemeriksaan terhadap olahan bawang putih giling ini dilakukan uji mikroba dengan metode MPN, metode MPN umumnya digunakan untuk menghitung jumlah bakteri khususnya untuk bakteri Coliform. Bakteri Coliform merupakan indikator alami baik di dalam air yang tampak jernih maupun air kotor yang berasal dari tanah dan air itu sendiri. Dalam metode MPN ini digunakan pemeriksaan dengan dua tahap test yaitu test penduga dan test penegasan. Pada saat melakukan uji penegas, media yang digunakan adalah BGLB, karena media BGLB merupakan media selektif untuk bakteri coliform.

Dalam penelitian ini peneliti menggunakan control Negatif dengan perlakuan tanpa menggunakan sampel. Tujuan digunakannya control Negatif yaitu untuk memastikan hasil penelitian yang positif tercemar bakteri Coliform itu benarbenar berasal dari sampel bukan dari media atau cara pengerjaannya. Jika pada tabung terdapat gelembung gas maka sampel tersebut positif coliform karena gelembung gas merupakan fermentasi laktosa oleh bakteri golongan coli. Pada sampel penelitian yang digunakan 19 sampel dan mendapatkan hasil yang berbeda - beda, jumlah bakteri yang positif ada 13 sampel sedangkan untuk jumlah bakteri coliform yang tertinggi terdapat pada sampel 6, 11, dan 18 yaitu berjumlah 10/100 mL.

\section{KESIMPULAN}

Berdasarkan hasil penelitian tentang uji bakteri coliform pada olahan bawang putih giling yang dijual di pasar tradisonal kota 
Bengkulu dapat disimpulkan : pada penelitian yang telah dilakukan terdapat bakteri coliform di 13 sampel dengan nilai presentase cemaran bakteri coliform $68,4 \% / 100 \mathrm{~mL}$ dan 6 sampel negatif bakteri coliform.

\section{SARAN}

\section{Bagi Masyarakat}

Diharapkan kepada masyarakat agar lebih berhati-hati lagi dalam memilih olahan bawang putih giling dengan cermat dan pintar, agar masakan yang dimasak sehat untuk di konsumsi.

2. Bagi Institusi Pendidikan

Hasil penelitian penelitian ini diharapkan nantinya dapat digunakan sebagai masukan referensi yang akan berguna bagi mahasiswa jurusan Analis Kesehatan tentang pemeriksaan bakteri Coliform pada olahan bawang putih giling.

\section{Bagi Peneliti Lain}

Bagi peneliti selanjutnya diharapkan dapat mengembangkan penelitian ini ditempat yang berbeda meneliti genus atau species koloni yang terdapat pada olahan bawang putih giling yang diteliti.

\section{DAFTAR PUSTAKA}

Br. Purba Kezia Ramayana, Santi Nuraini Devi, T. A. (2013) 'Analisis Higiene Sanitasi Pengolahan dan Pemeriksaan Bakteri E. coli pada Minuman Air Kelapa Muda Kecamatan Medann Tuntungan Medan Tahun 2013', Jurnal Kesehatan Masyarakat, pp. 1-12.

Bs, V. J. C., Ms, T. J. S., Bs, T. L., Bs, N. S., Bs, D. S. M., Bs, E. U., Bs, C. K., Bs, D. M. and Kavouras, J. H. (2016) 'American Journal of Infection Control Coliform bacteria, fabrics, and the environment', American Journal of Infection Control. Elsevier Inc, 43(2), pp. 154-158.doi: 10.1016/j.ajic.2014.11.001.

Fifendy, M. (2012) 'Uji Bakteriologis Cabai Merah Giling ( Capsicum Annum L . )
Dari Beberapa Pasar Tradisional Di Kota Padang'.

Hendrawati, Vivan S., Suyasa, Nyoman G., \& Sujaya, N. (2014) 'Efektivitas Larutan Bawang Putih (Allium sativa L.) dan Ketumbar (Coriandrum sativum) terhadap Daya Awet Tahu Lombok', Jurnal Kesehatan Lingkungan, 4(1), pp. 79-87.

Salter, R. S., Durbin, G. W., Bird, P., Fisher, K. and Crowley, E. (2016) 'Evaluation of Peel Plate??? EC for determination of E. coli and coliform or total coliform in dairy products', Journal of AOAC International, 99(1), pp. 153-169. doi: 10.5740/jaoacint.15-0254.

Sutton, S. (2010) 'The Most Probable Number Method and Its Uses in Enumeration, Qualification, and Validation', Journal of Validation Technology,16(3), pp. 35-38. doi: 10.1097/RLI.0b013e318234e75b.Compa rtmental. 